\title{
S sciendo
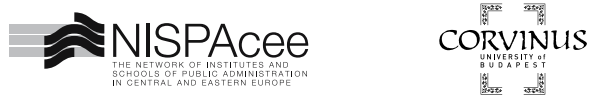

\section{The Potential of Design Thinking and Total Quality Management in Creating Public Value}

Rauno Vinni ${ }^{1}$

\begin{abstract}
One of the most fashionable management concepts currently is Design Thinking (DT). DT is sometimes advertised as the creative and innovative method for handling wicked problems. The explosion of DT in the public sector resembles the fast adoption of Total Quality Management (TQM) a few decades ago. At first sight, DT and TQM appear mutually exclusive - the former emphasizes inventiveness, which is cherished in modern governance, while the latter stresses mechanistic solutions and seems obsolete. Yet, public managers need a clearer understanding of DT and TQM and how they relate to each other. The main aim of this paper is two analyze when public managers should employ DT and when they should use TQM in creating public value. The article compares DT and TQM and finds that they are surprisingly similar. For example, they share core values like user-centeredness, stakeholder commitment, cooperation, etc. That is not to say that DT and TQM are the same, for instance their tools are different. Still, the paper argues that the two management models could well be combined - e.g. DT could assist public managers in finding new solutions to known problems and TQM could be used to institutionalize change. This insight helps managers to make informed decisions when choosing a mix of management methods that fits their purpose best.
\end{abstract}

\section{Keywords:}

Design thinking; total quality management; public management; public value.

\section{Introduction}

Public administrators are under endless pressure to achieve more with fewer resources (Bason 2014). This potential conflict of goals appears to be a permanent

1 Ragnar Nurkse Department of Innovation and Governance, Tallinn University of Technology, Tallinn, Estonia. 
state for many public managers. Dealing with the tensions that stem from this volatile, uncertain, complex, and ambiguous (VUCA) environment requires openness, flexibility, and adaptivity (van der Wal 2017). Design Thinking (DT) can be regarded as the answer to the pressures of the "VUCA world" because design has the potential to support change. DT has expanded beyond creating tangible artifacts into constructing complex systems, turning designers into facilitators and co-creators of new systems and services (Buehring and Bishop 2020). Within the managerial realm, DT has been labeled as the best way to be creative and innovate (Johansson-Sköldberg et al. 2013). It is often described as a subjective and emotional alternative to the structured, bureaucratic logic characterizing many large organizations (Carlgren et al. 2016). DT is currently heavily advertised in the public sector as a response to the difficulties of providing public services (Allio 2014). Furthermore, it is now used to shape and influence intricate human systems by focusing on innovation as a social process (Liedtka et al. 2018) and engender a "new spirit" of policy making (Kimbell and Bailey 2017).

DT arguably offers managers advanced tools and techniques. Several design thinkers have gone so far as to advocate for the overthrow of traditional modes of policy and governance in favor of this purportedly new and superior approach to social problem solving (Clarke and Craft 2019). Bason (2014) says that there appears to be an inherent clash between the logic of administrative organization and the sensibilities of designers: government is analytical, rational, logical, and uses deductive thinking, while design is about synthesis, emotions, intuition, and uses inductive thinking. Some proponents of DT elaborate that designers balance aspects such as feasibility and viability, creativity and constraints, analytical and intuitive thinking (Carlgren et al. 2016). This praise calls for an analysis of DT in the public sector.

The first research question of this article is whether DT is indeed conceptually exceptional. To answer that, DT and TQM are juxtaposed. The rhetoric of the supremacy of DT and its invasion into the public sector resembles the fast adoption of Total Quality Management (TQM) more than two decades ago (see Madsen 2020). At first sight, the two management philosophies seem totally distinct. DT is often associated with creative arts (Di Russo 2016) and TQM with bureaucracy and machine work (Hazlett and Hill 2000). Yet, both concepts originate from manufacturing and have roots in the rational problem-solving approach to management. This paper argues that the principles of DT are not that original, DT and TQM share several core values. This is far from saying that DT and TQM are the same; for example, their tools and techniques differ. However, DT and TQM could be used together. Public managers seeking to embed DT into their organization do not have to entirely replace "old tools of governance", despite the claims of some "true believers" of DT that this is necessary. 
The second research question addresses the potential of DT in delivering public value compared to TQM. As Barzelay (2019) argues, public management is for creating public value, and effectuating public value involves firstly performing a public organization's enterprise functions, including program-delivery and management, and secondly problem-solving in organizations. The latter is about doing the former better than would otherwise be the case. For Barzelay, public management is a design-oriented professional discipline (ibid.).

On the other hand, DT could also be regarded as an "artsy" private sector management fad that does not fit the realities of the public sector. This article claims that notwithstanding its boundaries (e.g. simple approaches do not always help with solving complex issues), DT has several virtues that are fresh to public organizations (e.g. tools of empathy, creativity, iteration, and experimentation) and match the realities of the "VUCA world". The challenge for public managers is how to find the most suitable tools to do the job at hand. The paper argues that when there is a need for creative and innovative solutions or when empathy and collaboration is needed to achieve social outcomes, DT could be the manager's first option. Also, when choice, personalization, and flexibility is essential, DT should be the primary managerial approach. If the operating environment is more stable and predictable, then planning, control, clear accountability, and transparency are key to delivering public value. In this case, TQM has a lot to offer.

The paper is divided into six parts. Section 1 is the introduction. The following two sections provide a literature review of the evolution, essence, methods, and critique of DT and TQM. This systematic overview is used as an input for comparing the two management ideas in the fourth part of the paper. The resemblances and variances are analyzed using general evaluation criteria established by the author. Section 5 addresses the question of how DT and TQM influence the creation of public value. The competing public values framework (CPVF) by Talbot (2008) is used to examine the issue because the model is a practical display of public values. CPVF contains the idea that managing public value is about elucidating paradoxes, which is also an intrinsic aspiration of DT. The article concludes with insights for public managers on using DT and TQM in public organizations in section 6.

\section{Overview of design thinking}

\subsection{Evolution of the concept}

There is no universally agreed definition of DT, but a short excursion into the history of DT may shed some light on the nature of the concept. Design theory and practice has for a long time dealt with objects. Management scholars first showed an interest in links between business and design in the mid-1980s (Johansson-Sköldberg et al. 2013). This phase is sometimes referred to as design management (DM), that is the ongoing management - and leadership - of design organizations, design 
processes, and designed outcomes (Cooper et al. 2009). The development of DM and DT could be presented in three stages (Table 1).

\section{Table 1}

The progression of DM and DT (the author, based on Cooper et al. 2009)

\begin{tabular}{|l|l|l|}
\hline \multicolumn{1}{|c|}{ Stage } & \multicolumn{1}{|c|}{ Drive } & \multicolumn{1}{c|}{ Approach to design } \\
\hline $\begin{array}{l}\text { 1. DM in the } \\
\text { context of } \\
\text { manufacturing }\end{array}$ & $\begin{array}{l}\text { DM deals with management issues } \\
\text { that are directly related to the } \\
\text { product development process } \\
\text { with the aim of succeeding in a } \\
\text { competitive market. }\end{array}$ & $\begin{array}{l}\text { Design adds value, which poses } \\
\text { questions such as: What value and } \\
\text { at what development stage does } \\
\text { design add to a manufactured } \\
\text { good? What is the role of the } \\
\text { designer in a product development } \\
\text { team? How can this value be } \\
\text { measured? }\end{array}$ \\
\hline $\begin{array}{l}\text { 2. DM in the } \\
\text { context of } \\
\text { marketing and } \\
\text { branding }\end{array}$ & $\begin{array}{l}\text { The product continues to be } \\
\text { mostly viewed as a good for sale, } \\
\text { and its purpose is still to succeed } \\
\text { in a competitive market. }\end{array}$ & $\begin{array}{l}\text { The focus is on a tangible product } \\
\text { together with its accompanying } \\
\text { services. Here the concept } \\
\text { of service design took shape } \\
\text { initially. Design's role is merely to } \\
\text { offer a service to the process of } \\
\text { manufacturing goods for sale. }\end{array}$ \\
\hline $\begin{array}{l}\text { 3. DM in the } \\
\text { context of } \\
\text { organizations } \\
\text { and society }\end{array}$ & $\begin{array}{l}\text { Design activities are established } \\
\text { parts of an organization, either } \\
\text { in manufacturing or in marketing } \\
\text { and branding. }\end{array}$ & $\begin{array}{l}\text { DM changed its course from one } \\
\text { of designing as managing to one } \\
\text { of managing as designing. Design } \\
\text { thinking emerged as a practice } \\
\text { independent of the product. DT } \\
\text { focused on the characteristics of a } \\
\text { problem. }\end{array}$ \\
\hline
\end{tabular}

In short, the approach, once used in production, is now infusing corporate culture (Kolko 2015) and can be applied to strategies, organizations, systems, services, and policies (Bason 2010). Sanders and Stappers (2008) go on by saying that design is about designing for the future experiences of people, communities and cultures. Le Masson et al. (2013) propose no less than a new paradigm for contemporary societies - the design paradigm.

\subsection{Ways of describing DT}

DT involves the implementation of a design philosophy; it is a precursor to design action (Chen 2019). Put otherwise, the essence of DT can be further clarified by examining its principles and features, which are explained in Table 2. 
Table 2

The features of DT based on two literature reviews

\begin{tabular}{|l|l|}
\multicolumn{1}{|c|}{$\begin{array}{c}\text { Principal attributes of DT } \\
\text { (Micheli et al. 2018) }\end{array}$} & $\begin{array}{c}\text { Commonly cited characteristics of DT } \\
\text { (Di Russo 2016) }\end{array}$ \\
\hline Creativity and innovation & Optimistic, inventive, and innovative \\
\hline User-centeredness and involvement & Empathy, human-centered \\
\hline Problem solving & Wicked problems \\
\hline Iteration and experimentation & Iterative \\
\hline Interdisciplinary collaboration & Collaborative, multidisciplinary \\
\hline Ability to visualize & Visualization \\
\hline Gestalt view* & Ethnographic \\
\hline Abductive reasoning** & $\begin{array}{l}\text { Abductive, intuitive, problem-solution } \\
\text { framing }\end{array}$ \\
\hline Tolerance of ambiguity and failure & Fuzzy front end, rapid, prototyping \\
\hline Blending rationality and intuition & System thinking \\
\hline
\end{tabular}

${ }^{*}$ Gestalt view is an integrative approach that enables both the development of a deeper understanding of the problem context and the identification of relevant insights (Micheli et al. 2018).

${ }^{* *}$ Abductive reasoning is the opposite of deductive thinking (from the general to the specific) and inductive reasoning (from the specific to the general); it is the imagination of what might be, rather than the analysis of what is; the abductive approach to problem solving is about either relying on an existing frame or reframing and challenging existing practices and assumptions (Micheli et al. 2018).

Table 3

Different ways of describing DT (Kimbell 2011)

\begin{tabular}{|l|l|l|l|}
\hline Focus & \multicolumn{1}{|c|}{$\begin{array}{c}\text { DT as a cognitive } \\
\text { style }\end{array}$} & \multicolumn{1}{|c|}{$\begin{array}{c}\text { DT as a general } \\
\text { theory of design }\end{array}$} & \multicolumn{1}{|c|}{$\begin{array}{c}\text { DT as an } \\
\text { organizational } \\
\text { resource }\end{array}$} \\
\hline $\begin{array}{l}\text { Design's } \\
\text { purpose }\end{array}$ & $\begin{array}{l}\text { Individual designers, } \\
\text { especially experts }\end{array}$ & $\begin{array}{l}\text { Design as a field or } \\
\text { discipline }\end{array}$ & $\begin{array}{l}\text { Businesses and other } \\
\text { organizations in need } \\
\text { of innovation }\end{array}$ \\
\hline Key concepts & $\begin{array}{l}\text { Design ability as a } \\
\text { form of intelligence; } \\
\text { reflection-inaction, } \\
\text { abductive thinking }\end{array}$ & $\begin{array}{l}\text { Design has no special } \\
\text { subject matter of its } \\
\text { own }\end{array}$ & $\begin{array}{l}\text { Visualization, } \\
\text { prototyping, empathy, } \\
\text { integrative thinking, } \\
\text { abductive thinking }\end{array}$ \\
\hline $\begin{array}{l}\text { Nature } \\
\text { of design } \\
\text { problems }\end{array}$ & $\begin{array}{l}\text { Design problems } \\
\text { are ill-structured, } \\
\text { the problem and the } \\
\text { solution co-evolve }\end{array}$ & $\begin{array}{l}\text { Design problems are } \\
\text { wicked problems }\end{array}$ & $\begin{array}{l}\text { Organizational } \\
\text { problems are design } \\
\text { problems }\end{array}$ \\
\hline $\begin{array}{l}\text { Sites of design } \\
\text { expertise and } \\
\text { activity }\end{array}$ & $\begin{array}{l}\text { Traditional design } \\
\text { discipline }\end{array}$ & $\begin{array}{l}\text { Four orders of design } \\
\text { (signs, things, actions, } \\
\text { and thoughts) }\end{array}$ & $\begin{array}{l}\text { Any context from } \\
\text { healthcare to access to } \\
\text { clean water }\end{array}$ \\
\hline
\end{tabular}


Johansson-Sköldberg et al. (2013) identified multiple approaches with different meanings given to the concept of DT. According to them there are five "designerly" ways of DT: (1) creation of artefacts, (2) reflexive practice, (3) problem-solving activity, (4) way of reasoning/making sense of things, (5) creation of meaning. In addition, there are three approaches that fall under DT as a management discourse: (1) the design company IDEO's way of working with design and innovation, (2) a way to approach indeterminate organizational problems, and a necessary skill for practicing managers, (3) part of management theory. Kimbell (2011) summarizes three main ways of describing DT that are summarized in Table 3.

The abundance of design interpretations demands further explanations of how DT is put into practice and how it is employed in the public sector. These topics are covered in the next sections.

\subsection{Methods and tools of DT}

Key elements of the DT methodology include early and frequent interaction with customers, fast iterations, decision-making, optimization, agile process design with less hierarchy, evaluation, and a learning-by-doing approach that involves building prototypes of any kind as early as possible in the process (Le Masson et al. 2013; Kupp et al. 2017).

Lindberg et al. (2010) say that there are two kinds of design process models: (1) explanatory-theoretical representation of design activities (an abstract model); (2) prescriptive statements on how to solve design problems (a practical model). A typical abstract DT model consists of these steps: discover (understanding the current situation), reframe (deep study of the current situation to understand it in non-obvious ways), envision (exploring potential solutions), and create (designing the future) (Mendel 2012). Practical models follow a similar logic. For example, a renowned model of the "double diamond" developed by the British Design Council (2015) consists of four stages:

1) Discover: insight into the solution;

2) Define: the area to focus upon;

3) Develop: potential solutions;

4) Deliver: solutions that work.

DT embraces a lot of hands-on techniques and tools that help designers to get through the design process. Micheli et al. (2018) mapped the essential tools of DT. These are ethnographic methods, personas, brainstorming, mind maps, visualization, prototypes, journey maps, and field experiments. Additionally, Mulgan (2014) brings out systems thinking because DT highlights the importance of seeing correlations between different parts of the system and asking the right questions. Mintrom and Luetjens (2016) use the term "DT strategies" and present a list of methods to use 
in the context of public policies - environmental scanning, participant observation, open-to-learning conversations, mapping, sensemaking - which can be combined to strengthen the targeting, development, and implementation of policies.

\subsection{DT in the public sector}

Until recently, most of the professional advice on the designers' part focused on the micro- and meso-levels of governance: on developing physical artefacts (e.g. buildings, public space) and later (digital) public services. Today, the scope of DT in the public sector has been extended to cover policy-making on the macro-level of governance (Mintrom and Luetjens 2016). Part of the attraction of employing DT in the public sector is the hope that design will advance public innovation (Mulgan 2014) and offer a different way of understanding policy problems, which comes from its hybrid blend of research methods from other disciplines, such as anthropology, systems thinking, and data science, thereby engendering collaboration between different parties and making policy tangible and graspable (Bason 2014; Kimbell and Bailey 2017). The assumed benefits of DT compared to "traditional" public administration are outlined in Table 4.

\section{Table 4}

The benefits of DT compared to traditional public administration (the author, based on Allio 2014; Kimbell and Bailey 2017; Clarke and Craft 2019)

\begin{tabular}{|l|l|}
\hline \multicolumn{1}{|c|}{ "Traditional" public administration } & \multicolumn{1}{c|}{ Advantages of DT } \\
\hline $\begin{array}{l}\text { "Closed" design processes, led by } \\
\text { government actors, with little attention to } \\
\text { real needs of users, absence of engagement }\end{array}$ & $\begin{array}{l}\text { Designing for the fundamental needs of } \\
\text { users and engaging citizens; "co"-modes } \\
\text { of doing, such as co-production and co- } \\
\text { delivery }\end{array}$ \\
\hline $\begin{array}{l}\text { Policy of program specific "silos", lack of } \\
\text { joined-up thinking }\end{array}$ & $\begin{array}{l}\text { Joined-up innovation process, } \\
\text { multidisciplinary teams; a comprehensive } \\
\text { problem perspective; integrated and better- } \\
\text { targeted solutions; reduced duplicated } \\
\text { efforts, policy inconsistencies or overlaps }\end{array}$ \\
\hline Long-term pre-implementation planning \\
processes & $\begin{array}{l}\text { Creativity and risk taking; regular iteration } \\
\text { and experimentation; low risk prototypes } \\
\text { that lead to innovative and inclusive } \\
\text { solutions; reducing the distance between } \\
\text { policy and implementation }\end{array}$ \\
\hline Ambiguous and complex goals & $\begin{array}{l}\text { Better understanding of the "architecture" } \\
\text { of a problem; generating new ideas }\end{array}$ \\
\hline Lack of tangibility & $\begin{array}{l}\text { Making problems tangible through direct } \\
\text { observation, visualization and prototypes; } \\
\text { enhanced synergies and better addressed } \\
\text { trade-offs }\end{array}$ \\
\hline
\end{tabular}

The positive impact of DT is of course not as straightforward as Table 4 might imply. As Kimbell and Bailey (2017) suggest, the adoption of design practices into 
policy settings has received mixed assessments. For example, design's traditional focus on experiences and serendipitous creativity might neglect a deep understanding of government systems and may be at odds with prevailing organizational cultures and practices. These tensions lead us to the critique of DT in the next part.

\subsection{The critique of DT}

DT contains a fundamental paradox where, on the one hand, DT is supposed to address wicked issues using out-of-the-box thinking, but on the other hand, design thinkers and implementers apply a rational process of manageable stages in order to reach a solution (see Dorst 2006). While there is no doubt that each design problem-solving consists of a certain sequence of process steps, the question would be how predictable, and thus, how determinable those sequences are (Lindberg et al. 2010).

Table 5

Main problems with using DT in the public sector

\begin{tabular}{|c|c|c|}
\hline DT & $\begin{array}{l}\text { "Traditional" public } \\
\text { administration }\end{array}$ & $\begin{array}{l}\text { Barriers of DT in the } \\
\text { public sector }\end{array}$ \\
\hline \multirow[t]{2}{*}{$\begin{array}{l}\text { Design synthesizes the } \\
\text { emotional and the intuitive } \\
\text { using inductive reasoning } \\
\text { and thinking from multiple } \\
\text { disciplines to create value } \\
\text { (Bason 2014). }\end{array}$} & $\begin{array}{l}\text { Relies on rational and logical } \\
\text { analysis and uses deductive } \\
\text { and thorough thinking } \\
\text { to come up with elegant } \\
\text { solutions, often influenced } \\
\text { by a single discipline like law } \\
\text { or economics (Bason 2014). }\end{array}$ & $\begin{array}{l}\text { Values and culture of DT } \\
\text { and "traditional" public } \\
\text { administration are in } \\
\text { conflict. }\end{array}$ \\
\hline & $\begin{array}{l}\text { Political context complicates } \\
\text { simplistic applications of } \\
\text { strict "user centrism" as } \\
\text { derived from private sector } \\
\text { experiences (Clarke and } \\
\text { Craft 2019). }\end{array}$ & $\begin{array}{l}\text { Design's traditional } \\
\text { focus on experiences } \\
\text { and serendipitous } \\
\text { creativity neglects a } \\
\text { deep understanding of } \\
\text { government systems and } \\
\text { practices (Kimbell and Bailey } \\
\text { 2017). }\end{array}$ \\
\hline $\begin{array}{l}\text { The ability to give shape } \\
\text { to abstract concepts and } \\
\text { ideas is a core design } \\
\text { skill (Bason 2014). Yet, } \\
\text { as the complexity of the } \\
\text { design process increases, } \\
\text { a new hurdle arises: the } \\
\text { acceptance of "the designed } \\
\text { artifact" - whether product, } \\
\text { user experience, strategy, } \\
\text { or complex system - by } \\
\text { stakeholders (Brown and } \\
\text { Martin 2015). }\end{array}$ & $\begin{array}{l}\text { The political, ideological, } \\
\text { and sometimes abstract } \\
\text { nature of public policies } \\
\text { makes them unfit for } \\
\text { design practices which are } \\
\text { concerned with that which } \\
\text { is attractive, functional, } \\
\text { and meaningful to people in } \\
\text { practice (Bason 2014). }\end{array}$ & $\begin{array}{l}\text { It is questionable whether } \\
\text { designers can be equal } \\
\text { partners in policy-making } \\
\text { and vice versa - it is } \\
\text { sometimes argued that civil } \\
\text { servants lack the skills and } \\
\text { values necessary to think } \\
\text { and act as designers. }\end{array}$ \\
\hline
\end{tabular}


Further arguments against DT are not surprising. Opponents say that DT is poorly defined, and this creates confusion; the case for its use relies more on anecdotes than data; it is little more than basic common sense, repackaged and then marketed for a hefty consulting fee (Iskander 2018). Kupp et al. (2017) state that the typical process of DT hardly ever works the way it is supposed to because of the following challenges: organizations whose success is built on predictable operations instinctively resist fuzzy and messy innovation processes; many established companies punish failure, which discourages the risk-taking that DT requires; DT teams need a lot of autonomy to function well. If these difficulties persist in the private sector, they could be even more grave in public organizations. Table 5 summarizes barriers to using DT in the public sector.

One can respond to the critique by saying that managing tensions is an intrinsic part of DT. For example, Dorst (2015) suggests that DT contains a process of thinking around the paradox rather than confronting it head-on. The solution is not within the core paradox itself, but in the broad area of contextual values and themes surrounding the paradox. So, the core activity of a designer is to create frames, i.e. standpoints from which a problem can be solved, and then concentrate on understanding what is at play in the broadened problem arena (Dorst 2015). Then again, there is no assurance that the creation of alternative frames helps to redefine a problem and find a solution that works.

\section{Overview of total quality management}

\subsection{Evolution of the concept}

Like design, quality is a vague concept that lies in the eye of the beholder (van Kemenade and Hardjono 2019). It could be viewed as something excellent; it could represent value to somebody; it could be defined as conformance to specifications; or it could be regarded as a bargain that meets or exceeds customer's expectations (Reeves and Bednar 1994). Four fairly discrete stages can be identified in the evolution of quality management (QM): inspection, quality control, quality assurance, and TQM. The first two stages are based on detection and treatment, while the latter two are based on problem prevention (van der Wiele et al. 1997).

Although many management scholars consider TQM to be a management fad of the 1980s and 1990s that has now passed, there are those who think that TQM is still alive (see Sabet et al. 2016; Madsen 2020) and now at a more mature stage where focuses have shifted from being initially on TQM to the tools, techniques, and core values which are needed to implement QM and build a quality and business excellence culture (Dahlgaard-Park et al. 2013). Efforts for the further development of QM encompass "perceived quality", "human-focused QM", and "intelligent QM" (Weckenmann et al. 2015). Some experts even argue that TQM is approaching, if 
not merging, innovation management (Lilja et al. 2017). In this paper, the term "TQM" is used throughout because it is widely used as a roof concept to denote various QM principles and practice.

\subsection{Ways of describing TQM}

As there is no universally agreed definition of TQM, numerous lists of its key elements have been proposed. Three examples are provided in Table 6.

\section{Table 6}

The features of TQM based on literature reviews

\begin{tabular}{|c|c|c|}
\hline $\begin{array}{l}\text { Top ten TQM critical } \\
\text { success factors } \\
\text { (Aquilani et al. 2017) }\end{array}$ & $\begin{array}{c}\text { TQM core principles } \\
\text { (Dahlgaard-Park 2011) }\end{array}$ & $\begin{array}{l}\text { Quality 4.0: eight key } \\
\text { ingredients of managing } \\
\text { quality in the Industry } \\
4.0 \text { era (Sony et al. } 2020 \text { ) }\end{array}$ \\
\hline $\begin{array}{l}\text { Leadership/top management } \\
\text { commitment/role of top } \\
\text { management }\end{array}$ & $\begin{array}{l}\text { Strong management com- } \\
\text { mitment/leadership/strate- } \\
\text { gically based }\end{array}$ & $\begin{array}{l}\text { Top management support } \\
\text { for } \\
\text { Quality } 4.0\end{array}$ \\
\hline Customer focus/satisfaction & $\begin{array}{l}\text { Focus on } \\
\text { customers/customer-driven } \\
\text { organization }\end{array}$ & Leadership in quality \\
\hline Training and education & $\begin{array}{l}\text { Focus on learning \& } \\
\text { innovation/training and } \\
\text { education }\end{array}$ & Training in Quality 4.0 \\
\hline $\begin{array}{l}\text { Measurement or metric } \\
\text { systems/data information } \\
\text { and analysis/quality data } \\
\text { and reporting }\end{array}$ & $\begin{array}{l}\text { Actions based on } \\
\text { facts/scientific approach }\end{array}$ & $\begin{array}{l}\text { Handling big data } \\
\text { Improving prescriptive } \\
\text { analytics }\end{array}$ \\
\hline $\begin{array}{l}\text { Supplier collaboration/man- } \\
\text { agement/supplier quality } \\
\text { (management) }\end{array}$ & $\begin{array}{l}\text { Building partnerships } \\
\text { between suppliers, } \\
\text { customers, and society }\end{array}$ & $\begin{array}{l}\text { Using Quality } 4.0 \text { for } \\
\text { effective } \\
\text { vertical, horizontal and end- } \\
\text { to-end integration }\end{array}$ \\
\hline Process quality management & Focus on processes & \\
\hline Continuous improvement & Continuous improvement & \\
\hline $\begin{array}{l}\text { TQM as a strategic } \\
\text { issue/planning/role of } \\
\text { quality department }\end{array}$ & $\begin{array}{l}\text { Total involvement/total } \\
\text { commitment/total } \\
\text { responsibilities }\end{array}$ & $\begin{array}{l}\text { Using Quality } 4.0 \text { for } \\
\text { strategic advantage }\end{array}$ \\
\hline $\begin{array}{l}\text { Employee commitment and } \\
\text { attitude/involvement }\end{array}$ & $\begin{array}{l}\text { Focus on employees/team- } \\
\text { work/motivation/empower- } \\
\text { ment }\end{array}$ & \\
\hline $\begin{array}{l}\text { Organizational } \\
\text { culture/quality } \\
\text { culture/organizational } \\
\text { climate/learning }\end{array}$ & $\begin{array}{l}\text { Systematic } \\
\text { approach/building a TQM } \\
\text { culture }\end{array}$ & $\begin{array}{l}\text { Organizational culture for } \\
\text { Quality } 4.0\end{array}$ \\
\hline
\end{tabular}

Another way to rationalize TQM is to say that a range of "soft", "hard", and "mixed" approaches to TQM can be differentiated (Hill 1995). "Soft" TQM emphasizes customer awareness and the duty of employees to take responsibility for qual- 
ity. Employee motivation is crucial for successful customer care because employees are empowered to deliver quality to internal and external customers. "Hard" TQM uses the traditional techniques of quality control and assurance and corresponds to the "management by fact". "Mixed" forms combine the two approaches (ibid.). Table 7 divides different forms of TQM to these three broad categories.

Table 7

Different ways of describing TQM

\begin{tabular}{|c|c|}
\hline Approach & Form of TQM \\
\hline \multirow{2}{*}{$\begin{array}{l}\text { "Hard" } \\
\text { TQM }\end{array}$} & $\begin{array}{l}\text { TQM as quality management is about managing quality in mass } \\
\text { production settings using statistical tools (e.g. control charts, flowcharts, } \\
\text { Statistical Process Control, etc.) for improving processes, although it goes } \\
\text { beyond mere tools by incorporating issues of quality control to managerial } \\
\text { functions, e.g. strategic planning and involving workforce (Yong and } \\
\text { Wilkinson 2001). }\end{array}$ \\
\hline & $\begin{array}{l}\text { TQM as systems management is based on the use of systems and } \\
\text { procedures for controlling quality. Quality systems entail having the } \\
\text { organizational structure, responsibilities, documented procedures and work } \\
\text { instructions, processes, and resources for implementing QM so that there is } \\
\text { a guiding framework to ensure that every time a process is performed the } \\
\text { same information, methods, skills, and controls are used and practiced in a } \\
\text { consistent manner (Yong and Wilkinson 2001). }\end{array}$ \\
\hline $\begin{array}{l}\text { "Soft" } \\
\text { TQM }\end{array}$ & $\begin{array}{l}\text { TQM as people management is focused on the more qualitative aspects, } \\
\text { such as greater customer orientation, employee involvement, team-working, } \\
\text { and generally better management of employees. Much significance is placed } \\
\text { on education and training, communication, and involvement of all employees } \\
\text { in the decision-making process that should lead to the mind shift that quality } \\
\text { is everybody's responsibility (Yong and Wilkinson 2001). }\end{array}$ \\
\hline \multirow{2}{*}{$\begin{array}{l}\text { "Mixed" } \\
\text { TQM }\end{array}$} & $\begin{array}{l}\text { TQM as re-engineering is about building "discontinuity" into the system } \\
\text { by radically rethinking and redesigning processes to achieve improvements } \\
\text { (Yong and Wilkinson 2001). Rather than taking processes as given, they } \\
\text { should be overturned, taking the customer's rather than management } \\
\text { control perspective. }\end{array}$ \\
\hline & $\begin{array}{l}\text { TQM as a new management paradigm states that it is the overall quality } \\
\text { of management that leads to better performance. There are several ways to } \\
\text { achieve higher quality of management, among which national quality awards } \\
\text { represent one option (Yong and Wilkinson 2001). }\end{array}$ \\
\hline
\end{tabular}

\subsection{Methods and tools of TQM}

Hellsten and Klefsjo (2000) argued that TQM contains the three interdependent components of core values, tools, and techniques. Examples of TQM's techniques are quality circles, quality function deployment, benchmarking, employee development, supplier partnership, process management, self-assessment, design of experiment (ibid.). Tools of TQM are, for instance, relation diagrams, factorial design, Ishikawa diagrams, control charts, ISO 9000, process maps, tree diagrams, criteria of quality awards (although the latter are often treated separately as frameworks or 
models) (Dahlgaard-Park et al. 2013). Van Kemenade and Hardjono (2019) add instruments that are more in line with current understandings of TQM, e.g. reflexive tools (like second opinion, intervision, time-out, discussion stories, inner conversations, shadowing, modeling, peer review, Six Sigma) and systems management methods that help to make sense of chaos (for instance, context analysis, quality circles, Lean, appreciative inquiry, Socratic café). The extensive catalogue of methods demonstrates that the TQM toolbox has been expanding over time. It almost seems that every popular management instrument could be treated a part of TQM.

\subsection{TQM in the public sector}

It is argued that adopting quality principles might resolve difficulties that public organizations face easier and allow them to operate with lower cost and less effort (Tomaževič et al. 2014). Even so, Swiss (1992) argues that the orthodox (i.e. hard) TQM is strikingly ill-suited to the government environment, the major problems being its insufficient modification for services since service provision is usually more difficult to manage than manufacturing products, difficulties with defining customers, inappropriate emphasis on inputs and processes, which creates problems of measurement. Hazlett and Hill's (2000) study showed that the characteristics obstructing TQM in the public sector are the following: public sector culture, lack of clear customer focus, too many procedures, people working in divisional "silos", too many targets, lack of awareness of a strategic direction, the general belief that staff are overworked and underpaid, domination by stakeholders. Therefore Swiss (1992) proposed that a "reformed" TQM that emphasizes client feedback, performance monitoring, continuous improvement, and worker participation could be suited to public organizations. Fryer et al. (2007) elaborate that the most important success factor of TQM in the public sector is the management commitment.

Various QM methods and tools are now widespread in public organizations, e.g. service standards, management systems based on ISO 9000 series standards, "excellence" or benchmarking models, such as Common Assessment Frameworks (CAF), quality award programs and so on (see, for instance, how QM developed in Czechia in Špaček 2018 and examples of QM instruments in use in Špalková et al. 2015). A widening from quality of products and processes to quality of services, quality of life, and quality of the environment has taken place, and the challenge is to adjust and modify the QM framework while endlessly developing better tools and techniques in order to fit with the needs of new service and knowledge intensified organizations (Dahlgaard-Park et al. 2013). Raja Sreedharan, Raju, and Srivatsa Srinivas (2017) say that there is a need for process improvements in new governance settings, though quality principles need to be properly modified in different government departments like education, administration, etc. depending on the environment of each of these divisions to ensure that multiple, contradicting factors are taken into account as this area is somewhat sensitive. 


\subsection{The critique of TQM}

Apart from the discussion on TQM's suitability for public agencies, there has been a lively discussion about the downsides of TQM as such. One of the most serious objections to TQM is that it creates mechanistic solutions (Godfroij 1995) and increases bureaucracy (Hill and Wilkinson 1995). Dahlgaard-Park (2011) brings out three lines of criticism. First, the failure rate of TQM implementation is high, although it is frequently not clear whether the organizations which experienced failure really adopted TQM or not. The second criticized aspect of TQM concerns its position as a general management theory: there is no consensus on TQM terminology and definitions and its main tenets are not all unique to TQM, but they are also part of other organizational change initiatives or generally accepted "good" management practices; organizational contingencies are not recognized, organizational informal aspects, such as power and politics, are either completely forgotten or viewed as having little importance. Third, TQM is strong on the implementation aspect but weak on content (ibid.)

\section{Comparison of DT and TQM}

The rhetoric of the proponents of TQM back in the 1980s and 1990s is comparable to the practitioner-advocates of DT in that the adoption of the respective management methods allegedly provides a quick fix to the problems (public) managers are facing. But the sales stories are not the only features DT and TQM share. The parallels and variances of these management concepts are discussed in Table 8.

The comparison shows that there are no fundamental differences in the scope, core principles and role of the main participants of DT and TQM. Divergences appear in practice. Designers use various tools that are (or used to be) unfamiliar to other disciplines. But as Dorst (2011) suggests, many of the activities that designers do are universal, and thus, it would be inappropriate to claim that these are exclusive to design. That is, there are no barriers to using methods of DT (e.g. personas or user journeys, etc.) in organizations that rely on TQM, and vice versa - DT can use tools (for example data analysis) inherent in TQM. This is possible because the core philosophy of the two management ideologies is wide-ranging and analogous, even more so because both TQM and DT are developing towards becoming general management concepts.

This is not to say that DT and TQM are the same. Obviously, DT does not resemble the "hard" version of TQM, which sees QM as the use of statistical tools to control processes and standardize end products. DT also differs from a conception of TQM as a systems management that relies on a control framework through documented processes and work instructions, clear structure and responsibilities, etc. In brief, it is apparent that "soft" versions of TQM are more related to DT and "hard" versions of TQM have less in common with DT. But in which situations could DT and/or TQM be most valuable? 


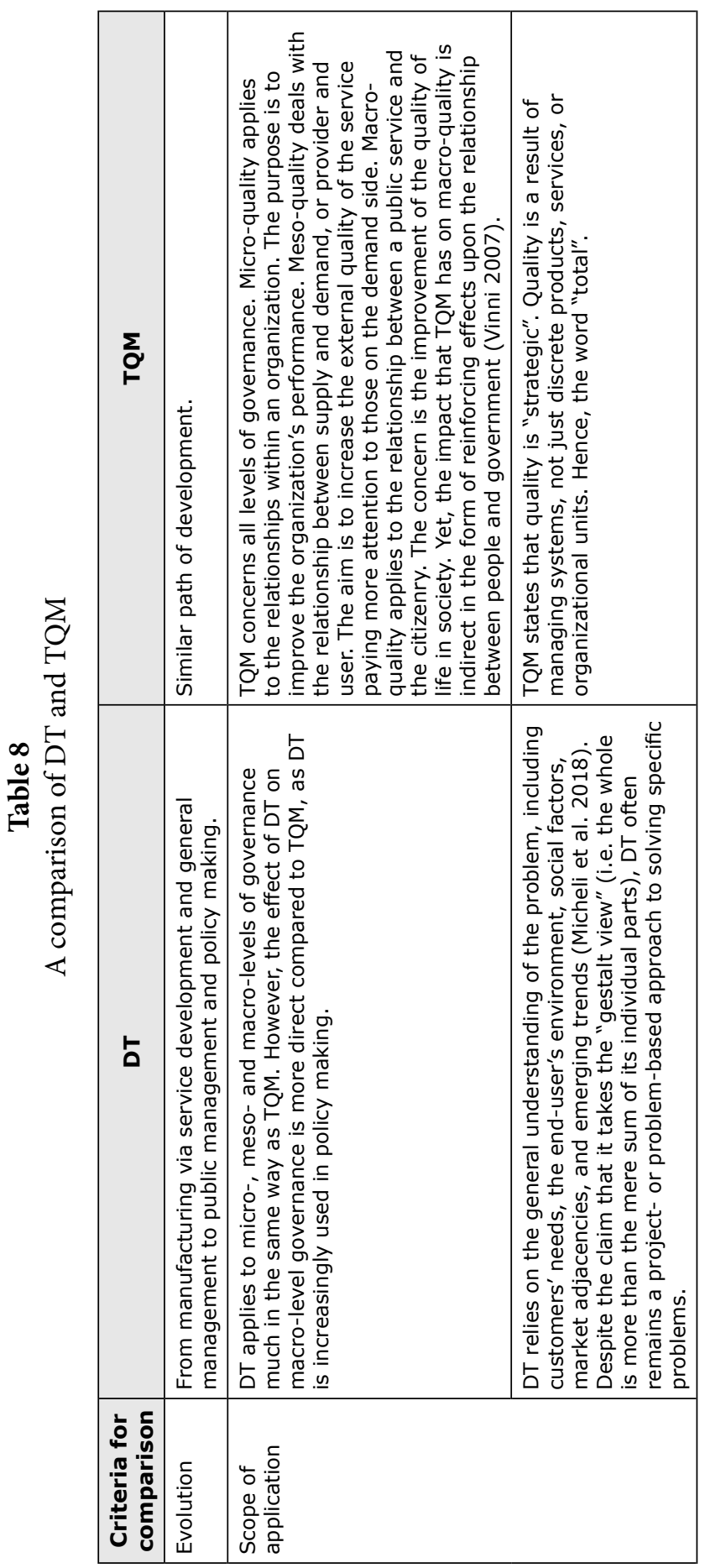




\begin{tabular}{|c|c|c|c|c|c|c|c|c|}
\hline 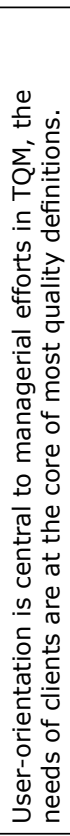 & 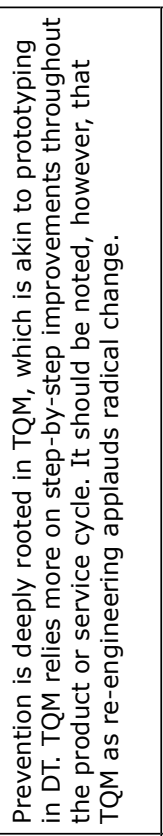 & 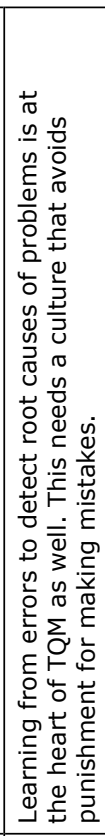 & 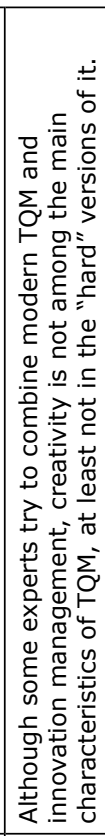 & 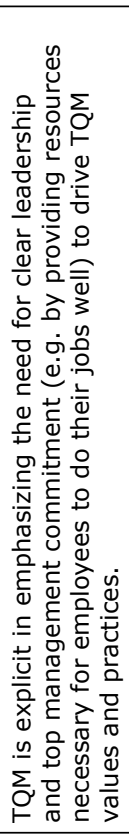 & 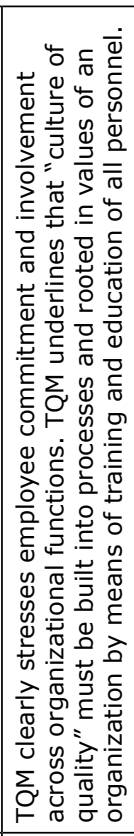 & 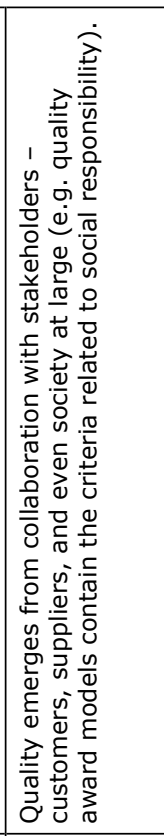 & 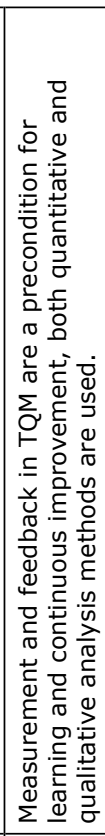 & 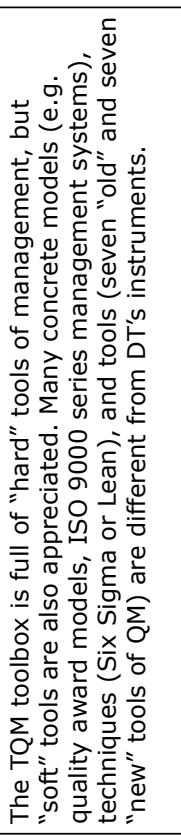 \\
\hline 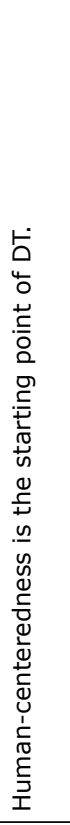 & 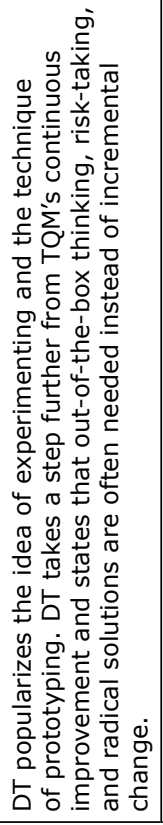 & 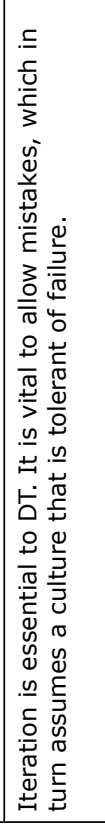 & 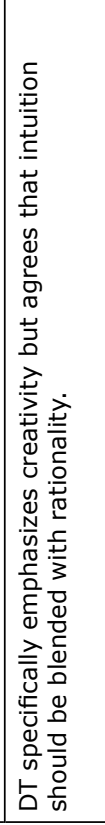 & 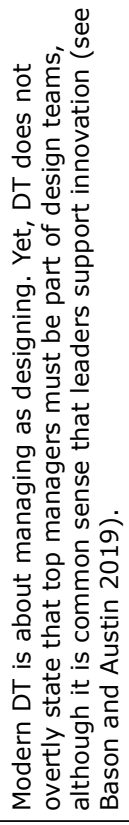 & 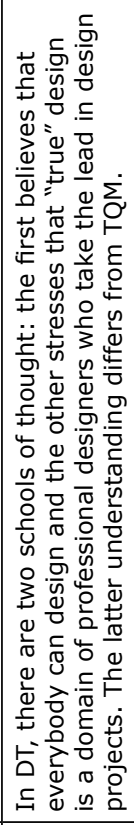 & 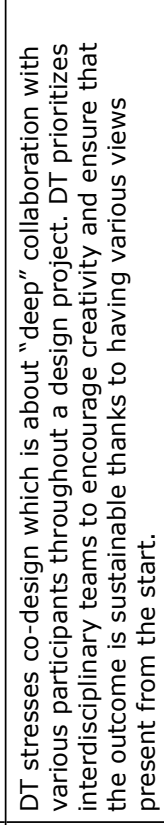 & 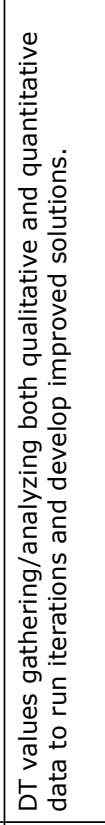 & 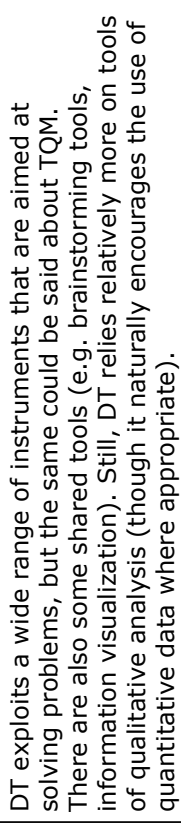 \\
\hline \multicolumn{4}{|l|}{ } & 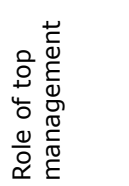 & 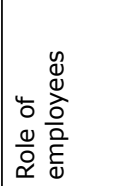 & 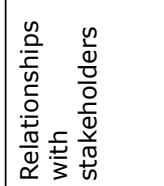 & 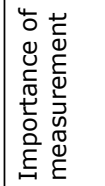 & \\
\hline
\end{tabular}




\section{The contribution of TQM and DT in creating public value}

Junginger (2018) argues that DT's focus on human interaction promotes innovation, integrates public organizations in a new way, and directly contributes to the creation of public value. But exactly how does DT, compared to TQM, influence public value creation? This could be analyzed using the competing public values framework (CPVF) by Talbot (2008). CPVF covers diverse goals that a public manager must consider and harmonizes five competing dimensions of public value: (1) trust and legitimacy; (2) collectivity; (3) security; (4) personal utility; and (5) autonomy (Talbot 2008) (see Table 9).

\section{Table 9}

Competing public values in relation to DT and TQM

\begin{tabular}{|c|c|c|c|}
\hline $\begin{array}{l}\text { Competing } \\
\text { public values } \\
\text { and their key } \\
\text { elements } \\
\text { (Talbot 2008) }\end{array}$ & $\begin{array}{c}\text { How does DT } \\
\text { influence public } \\
\text { values? }\end{array}$ & $\begin{array}{c}\text { How does TQM } \\
\text { influence public } \\
\text { values? }\end{array}$ & $\begin{array}{c}\text { Which management } \\
\text { idea works } \\
\text { better for public } \\
\text { managers? }\end{array}$ \\
\hline $\begin{array}{l}\text { COLLECTIVITY: } \\
\text { - Social } \\
\text { outcomes } \\
\text { - Co-production } \\
\text { - Social capital } \\
\text { and cohesion } \\
\text { - Partnerships } \\
\text { Collaboration } \\
\text { is at the core } \\
\text { of managerial } \\
\text { efforts in this } \\
\text { value area. }\end{array}$ & $\begin{array}{l}\text { DT values collectivity, } \\
\text { its characteristics } \\
\text { include co-design, } \\
\text { empathy, optimism, } \\
\text { collaboration, } \\
\text { multidisciplinary, } \\
\text { ethnographic methods, } \\
\text { etc. Yet, the direct } \\
\text { user is the focal point } \\
\text { of design activities } \\
\text { while concerns of } \\
\text { other stakeholders } \\
\text { are subsidiary. Then } \\
\text { again, many DT } \\
\text { experts stress that } \\
\text { nowadays design's } \\
\text { most important task is } \\
\text { to contribute to social } \\
\text { issues. }\end{array}$ & $\begin{array}{l}\text { TQM is a universal } \\
\text { concept that does } \\
\text { not differentiate } \\
\text { between (groups of) } \\
\text { stakeholders. TQM } \\
\text { values partnerships } \\
\text { and co-production } \\
\text { since quality is a } \\
\text { result of everyone } \\
\text { working together. } \\
\text { TQM does not aim } \\
\text { at maximizing } \\
\text { social outcomes } \\
\text { because often the } \\
\text { idea is to determine } \\
\text { acceptable or even } \\
\text { minimum standards } \\
\text { and concentrate } \\
\text { on staying within } \\
\text { defined parameters } \\
\text { at a minimal cost } \\
\text { (although supporters } \\
\text { of modern TQM } \\
\text { might argue that } \\
\text { it values social } \\
\text { outcomes as } \\
\text { manifested, for } \\
\text { example, in the } \\
\text { criteria of quality } \\
\text { award models). }\end{array}$ & $\begin{array}{l}\text { If collectivity and } \\
\text { collaboration is the } \\
\text { primary concern for } \\
\text { public managers, } \\
\text { DT could be the } \\
\text { answer due to in-built } \\
\text { methods and tools of } \\
\text { cooperation. } \\
\text { While TQM also } \\
\text { stresses collaboration, } \\
\text { it might guide } \\
\text { executives too much } \\
\text { into the direction of } \\
\text { minimum standards, } \\
\text { which is fine when in } \\
\text { search of stability, but } \\
\text { not when there is a } \\
\text { need to come up with } \\
\text { disruptive ideas. }\end{array}$ \\
\hline
\end{tabular}




\begin{tabular}{|c|c|c|c|}
\hline $\begin{array}{l}\text { AUTONOMY: } \\
\text { - Transparency } \\
\text { - Accountability } \\
\text { - Consultation } \\
\text { and } \\
\text { participation } \\
\text { - Innovation } \\
\text { Creativity } \\
\text { is central to } \\
\text { managerial } \\
\text { strategy in this } \\
\text { area of public } \\
\text { value. }\end{array}$ & $\begin{array}{l}\text { DT emphasizes } \\
\text { consultation and } \\
\text { participation. DT } \\
\text { could provide public } \\
\text { managers with fresh } \\
\text { methods of ideation } \\
\text { and creativity (Mulgan } \\
\text { 2014) that support } \\
\text { innovation. } \\
\text { However, the word } \\
\text { "accountability" is not } \\
\text { in designers' everyday } \\
\text { vocabulary (here } \\
\text { accountability to the } \\
\text { public is meant, not } \\
\text { to the profession) } \\
\text { and the messy design } \\
\text { process is not always } \\
\text { clear and transparent. }\end{array}$ & $\begin{array}{l}\text { TQM values } \\
\text { accountability } \\
\text { (responsibilities must } \\
\text { be precisely in place) } \\
\text { and consultation } \\
\text { with customers, as } \\
\text { well as transparency } \\
\text { since procedures } \\
\text { must be clear and } \\
\text { understandable to } \\
\text { everyone. } \\
\text { Although proponents } \\
\text { of modern TQM try } \\
\text { to bind TQM and } \\
\text { innovation together, } \\
\text { creativity is not the } \\
\text { primary concern of } \\
\text { quality managers. }\end{array}$ & $\begin{array}{l}\text { Taking TQM only } \\
\text { as a mechanistic } \\
\text { approach that is the } \\
\text { opposite of innovation } \\
\text { might point us in } \\
\text { the wrong direction } \\
\text { (e.g. visualization, } \\
\text { creativity-boosting, } \\
\text { and problem-solving } \\
\text { tools are in the arsenal } \\
\text { of quality managers). } \\
\text { Nevertheless, } \\
\text { creativity is more } \\
\text { deeply rooted in DT } \\
\text { than in TQM, and in } \\
\text { need of creative and } \\
\text { novel solutions, DT } \\
\text { may be the preferred } \\
\text { approach. TQM is } \\
\text { beneficial in situations } \\
\text { where clear and } \\
\text { transparent action is } \\
\text { needed. }\end{array}$ \\
\hline $\begin{array}{l}\text { SECURITY: } \\
\text { - Reliability and } \\
\text { resilience } \\
\text { - Service } \\
\text { standards } \\
\text { - Equity and due } \\
\text { process } \\
\text { - Costs and } \\
\text { efficiency } \\
\text { Control is the } \\
\text { central feature } \\
\text { of managerial } \\
\text { efforts in this } \\
\text { value area. }\end{array}$ & $\begin{array}{l}\text { DT could be useful in } \\
\text { creating sustainable } \\
\text { results, which is in } \\
\text { line with reliability } \\
\text { and resilience since } \\
\text { DT values developing } \\
\text { robust applications } \\
\text { via experimenting } \\
\text { and involvement of } \\
\text { stakeholders from } \\
\text { the start. Costs and } \\
\text { efficiency are not the } \\
\text { first concern of DT, } \\
\text { although in the longer } \\
\text { term the idea is to } \\
\text { offer value for money } \\
\text { through working out } \\
\text { lasting solutions. }\end{array}$ & $\begin{array}{l}\text { TQM, especially } \\
\text { the "hard" versions } \\
\text { of it, is to a great } \\
\text { extent about } \\
\text { institutionalizing } \\
\text { the processes at } \\
\text { optimum levels of } \\
\text { quality and cost to } \\
\text { maintain control. }\end{array}$ & $\begin{array}{l}\text { TQM has more to offer } \\
\text { to public managers in } \\
\text { securing services that } \\
\text { are reliable and meet } \\
\text { the required standards } \\
\text { (whether it be equity } \\
\text { or efficiency) that } \\
\text { apply to all groups } \\
\text { in the same way. In } \\
\text { other words, TQM } \\
\text { works well in internal } \\
\text { operations, stable } \\
\text { environments, and } \\
\text { uniform interactions, } \\
\text { while DT could be } \\
\text { useful in developing a } \\
\text { working solution in the } \\
\text { first place. }\end{array}$ \\
\hline
\end{tabular}


Table 9

(continuation)

\begin{tabular}{|c|c|c|c|}
\hline $\begin{array}{l}\text { PERSONAL } \\
\text { UTILITY: } \\
\text { - Choice } \\
\text { - Personalization } \\
\text { and flexibility } \\
\text { - Accessibility } \\
\text { - Relative } \\
\text { quality } \\
\text { Competition } \\
\text { is at the heart } \\
\text { of managerial } \\
\text { strategy in this } \\
\text { value area. }\end{array}$ & $\begin{array}{l}\text { Personalization, } \\
\text { flexibility, and choice } \\
\text { are deeply rooted in } \\
\text { DT, because it aims } \\
\text { at maximizing the } \\
\text { outcome for a specific } \\
\text { user group. Individual } \\
\text { needs of users are } \\
\text { more important } \\
\text { than social cohesion } \\
\text { (although many } \\
\text { design thinkers would } \\
\text { probably disagree with } \\
\text { this argument). }\end{array}$ & $\begin{array}{l}\text { One definition of } \\
\text { quality is that it } \\
\text { is what the users } \\
\text { define it to be, } \\
\text { and hence, TQM } \\
\text { stresses customer } \\
\text { orientation. } \\
\text { Therefore, in } \\
\text { some contexts, } \\
\text { relative quality is } \\
\text { tolerated in TQM } \\
\text { and personalization } \\
\text { is allowed. Despite } \\
\text { that, TQM works } \\
\text { better in providing } \\
\text { standardized } \\
\text { products and } \\
\text { services. }\end{array}$ & $\begin{array}{l}\text { When public managers } \\
\text { need to maximize } \\
\text { competition, } \\
\text { personalization, } \\
\text { and flexibility, DT } \\
\text { is a better option } \\
\text { - DT experts have } \\
\text { developed practical } \\
\text { tools (e.g. empathy } \\
\text { and/or experience } \\
\text { maps, etc.) that could } \\
\text { be of help to public } \\
\text { managers in coping } \\
\text { with the trend of } \\
\text { growing individuality } \\
\text { in society. However, } \\
\text { in situations where } \\
\text { relative quality is } \\
\text { unavoidable, TQM does } \\
\text { not rule out endeavors } \\
\text { of flexibility and } \\
\text { competition. }\end{array}$ \\
\hline $\begin{array}{l}\text { TRUST AND } \\
\text { LEGITIMACY } \\
\text { result from } \\
\text { other values } \\
\text { and stress the } \\
\text { need to balance } \\
\text { all dimensions } \\
\text { of CPVF to } \\
\text { uphold trust and } \\
\text { legitimacy of } \\
\text { governance. }\end{array}$ & \multicolumn{3}{|c|}{$\begin{array}{l}\text { Both DT and TQM contribute to building trust and legitimacy as } \\
\text { shown in the public value areas above. Furthermore, since trust } \\
\text { and legitimacy are ultimately assessed by the public (individually or } \\
\text { collectively) and the principle of human- or user-centricity is central } \\
\text { in both management concepts, it follows that confidence towards } \\
\text { the state should be a key concern for public managers in search of } \\
\text { delivering public value applying either DT or TQM. }\end{array}$} \\
\hline
\end{tabular}

Public managers must be acquainted with the ideas and methods of DT and TQM if they want to succeed in the practice of public policy or management. It is helpful to have a general understanding of which management concept is better suited to which circumstances. Table 9 illustrates that in some instances (e.g. where there is a need to get to the bottom of complex phenomena and/or develop new services or revolutionary solutions to policy problems), DT could be of more use. In some conditions (e.g. when there is a need to ensure that new solutions will be institutionalized into steady routines to guarantee uniform outcomes), TQM works well. But the key insight is that in many cases DT and TQM could be combined to achieve public goals, i.e. they are not mutually exclusive.

Surely there are situations where contradictions emerge when applying DT and TQM together - e.g. despite the similarities in basic principles, the strife for 
efficiency and workflow standardization can be counterproductive to the DT-led problem solving that aims to re-frame wicked problems and adapt to the ambiguity. Yet, this paper argues that the tension could be alleviated. Gaim and Wåhlin (2016) propose that it is possible to solve paradoxes in management by using design that stresses finding creative solutions that reconcile dilemmas, instead of just being forced to choose between option A or B. Dorst (2015) offers another practical point for managers - DT techniques and methods should be adapted, not adopted. Adaption means that core principles are transposed to other fields by practitioners abstracting from everyday design practices and connecting these fundamentals with the corresponding needs in the target field. Adoption is used when methods are chosen and applied without substantial change or much thought (ibid.).

\section{Conclusions}

This paper maintains that DT is not a silver bullet in addressing problems of public policy and management. DT is essentially a structured decision-making method which is relatively similar to the ideas of TQM, particularly to the "soft" and contemporary versions of it (e.g. TQM as a management paradigm). This may be good news for public management theorists and practitioners alike, because public sector organizations that have experience with QM may find that DT principles are not at odds with TQM. This could also help overcome the disadvantage of DT that it is often associated with arts and fashion, giving rise to skepticism in applying "artsy" ways to serious matters like health or education or social services. The article claims that DT promotes ideas that are valuable to modern public organizations, e.g. empathy, creativity, iteration, and experimentation. In a "VUCA world", the guiding role of (organizational) values is even greater than before. Since the core principles of DT and TQM are similar, public managers can apply them in parallel to achieve better outcomes in delivering public value.

For the enthusiasts of using DT in the public sector, a reminder that DT has its limits is appropriate. The key promise of advocates of DT is that it provides actual help in dealing with the wicked issues of public policy. However, the main critique of DT is that design itself is ill-equipped for solving the paradoxical situations where opposing views have to be unified. In other words, there is no guarantee that DT can yield solutions to complex problems - design is often reduced to simple recipes of innovation, but unpretentious methods often cannot unravel multifaceted social matters. Indeed, design thinkers suggest that creative solutions that draw on multiple perspectives can help to reconcile this inconsistency (see Gaim and Wåhlin 2016), but some tensions will probably remain. On the other hand, managing paradoxes in delivering results is a normal state of affairs for public managers, as established in the concept of CPVF (Talbot 2008). 
For practitioners, DT's value for public management might lie in putting people, not experts, at the center of development. Additionally, public managers might be attracted by the promise of DT that it could be used to develop ideas into solutions faster than public organizations are accustomed to. DT asks managers to look at the subject through various lenses, e.g. using knowledge from various fields affecting the problem. Therefore, engagement of various stakeholders, not just relying on professional designers, is essential in design projects (see also Mulgan 2014). TQM could prove useful in institutionalizing the (innovative) solutions that were created using DT approaches. In brief, when choosing the managerial method that fits the problem at hand, public managers should bear the following in mind:

- when there is a need for creative and innovative solutions and when empathy and collaboration are needed to achieve social outcomes, DT could be the manager's first choice;

- where detailed planning, control, clear accountability, and transparency is the key to delivering public value, TQM has more to offer;

- when competition is required to spur choice, personalization, and flexibility, DT should be the primary managerial option;

- when issues of trust and legitimacy are the main concern, both managerial approaches are helpful. DT and TQM could be applied jointly to create public value in a balanced manner.

This article dealt with the issue of contextualizing the utilization of management methods, taking into consideration the value proposition that a public organization pursues. Yet, variables beyond the purpose of public managers may influence the "right" mix of management instruments. For example, the degree of organizational publicness (see Antonsen and Jorgensen 1997) might be of importance. Publicness is organizational attachment to public sector values: for example, due process, accountability, and welfare provision. Organizations with a high degree of publicness are characterized by complex tasks, professional orientation, many external stakeholders, conflicting environmental demands, and low managerial autonomy. The latter are the opposite (ibid.). It follows that organizations with a low degree of publicness lend themselves more readily to managerial ideas. Organizations with a high degree of publicness find it harder to accommodate managerial interventions (Vinni 2007). In short, publicness is an example of a concept that presents opportunities for further research on how to contextualize the use of DT and TQM in CEE public management. 


\section{References}

Allio, L. 2014. Design Thinking for Public Service Excellence. Singapore: Global Centre for Public Service Excellence, United Nations Development Programme. Available at https://www.undp.org/content/dam/uspc/docs/GPCSE_Design\%20Thinking.pdf (last accessed 4 April 2021).

Antonsen, M. and T. B. Jorgensen. 1997. “The 'Publicness' of Public Organizations.” Public Administration 75 (Summer), 337-357.

Aquilani, B., A. Silvestri, A. Ruggieri and C. Gatti. 2017. "A Systematic Literature Review on Total Quality Management Critical Success Factors and the Identification of New Avenues of Research.” TQM Journal 29(1), 184-213.

Barzelay, M. 2019. Public Management as a Design-Oriented Professional Discipline. Cheltenham, UK: Edward Elgar Publishing Ltd. Available at https://doi. org/10.4337/9781788119108 (last accessed 4 April 2021).

Bason, C. 2010. Leading Public Sector Innovation: Co-Creating for a Better Society. Bristol, UK: Policy Press.

Bason, C. 2014. "Introduction: The Design for Policy Nexus." In C. Bason (ed.). Design for Policy. Surrey, UK: Gower Publishing, 1-8.

Bason, C. and R. D. Austin. 2019. “The Right Way to Lead Design Thinking." Harvard Business Review 97(2), 82-91.

British Design Council. 2015. The Design Process: What is the Double Diamond? Available at https://www.designcouncil.org.uk/news-opinion/design-process-what-double-diamond (last accessed 4 April 2021).

Brown, T. and R. Martin. 2015. "Design for Action: How to Use Design Thinking to Make Great Things Actually Happen." Harvard Business Review 93(9), 57-64.

Buehring, J. and P. C. Bishop. 2020. "Foresight and Design: New Support for Strategic Decision Making." She Ji: The Journal of Design, Economics, and Innovation 6(3), 408-432.

Carlgren, L., M. Elmquist and I. Rauth. 2016. "Exploring the Use of Design Thinking in Large Organizations: Towards a Research Agenda." Swedish Design Research Journal 1, 23-32.

Chen, S. 2019. The Design Imperative: The Art and Science of Design Management. Basingstoke: Palgrave Macmillan.

Clarke, A. and J. Craft. 2019. “The Twin Faces of Public Sector Design.” Governance $32,5-21$.

Cooper, R., S. Junginger and T. Lockwood. 2009. "Design Thinking and Design Management: A Research and Practice Perspective." Design Management Review 20(2), 46-55. 
Dahlgaard-Park, S. M. 2011. “The Quality Movement: Where are you Going?” Total Quality Management 22(5), 493-516.

Dahlgaard-Park, S. M., C.-K. Chen, J.-Y. Jang and J. J. Dahlgaard. 2013. "Diagnosing and Prognosticating the Quality Movement: A Review on the 25 Years Quality Literature (1987-2011).” Total Quality Management \& Business Excellence 24(1-2), 1-18.

Di Russo, S. 2016. Understanding the Behaviour of Design Thinking in Complex Environments. $\mathrm{PhD}$ diss. Swinburne Theses Collection. Available at http://hdl. handle.net/1959.3/419027 (last accessed 4 April 2021).

Dorst, K. 2006. “Design Problems and Design Paradoxes." Design Issues 22(3) 4-17.

Dorst, K. 2011. “The Core of 'Design Thinking' and its Application." Design Studies 32(6), 521-532.

Dorst, K. 2015. "Frame Creation and Design in the Expanded Field." She Ji, The Journal of Design, Economics, and Innovation 1, 22-33.

Fryer, K. J., J. Antony and A. Douglas. 2007. "Critical Success Factors of Continuous Improvement in the Public Sector: A Literature Review and Some Key Findings." The TQM Magazine 19(5), 497-517.

Gaim, M. and N. Wåhlin. 2016. "In Search of a Creative Space: A Conceptual Framework of Synthesizing Paradoxical Tensions." Scandinavian Journal of Management 32(1), 33-44.

Godfroij, A. J. A. 1995. "Evaluation in the Private Sector: Evolution and Professionalization of Quality Management." Knowledge \& Policy 8(3), 55-71.

Hazlett, S.-A. and F. Hill. 2000. "Policy and Practice: An Investigation of Organizational Change for Service Quality in the Public Sector in Northern Ireland." Total Quality Management 11(4-6), 515-520.

Hellsten, U. and B. Klefsjo. 2000. "TQM as a Management System Consisting of Values, Techniques and Tools.” The TQM Magazine 12(4), 238-244.

Hill, S. 1995. "From Quality Circles to Total Quality Management." In A. Wilkinson and H. Willmott (eds). Making Quality Critical: New Perspectives on Organizational Change. London: Routledge, 33-53.

Hill, S. and A. Wilkinson. 1995. "In Search of TQM." Employee Relations 17(3), 8-25.

Iskander, N. 2018. "Design Thinking is Fundamentally Conservative and Preserves the Status Quo." Harvard Business Review Online Resource, 5 September. Available at https://hbr.org/2018/09/design-thinking-is-fundamentally-conservative-and-preserves-the-status-quo (last accessed 4 April 2021). 
Johansson-Sköldberg, U., J. Woodilla and M. Çetinkaya. 2013. "Design Thinking: Past, Present and Possible Futures." Creativity and Innovation Management 22(2), 121-146.

Junginger, S. 2018. "Inquiring, Inventing and Integrating: Applying Human-Centered Design to the Challenges of Future Government." JeDEM: EJournal of EDemocracy and Open Government 10(2), 23-32.

Kimbell, L. 2011. "Rethinking Design Thinking: Part I." Design and Culture 3(3), 285-306.

Kimbell, L. and J. Bailey. 2017. "Prototyping and the New Spirit of Policy-Making." CoDesign 13(3), 214-226.

Kolko, J. 2015. "Design Thinking Comes of Age." Harvard Business Review 93(9), 66-71.

Kupp, M., J. Anderson and J. Reckhenrich. 2017. "Why Design Thinking in Business needs a Rethink." MIT Sloan Management Review 59(1), 41-44.

Le Masson, P., K. Dorst and E. Subrahmanian. 2013. "Design Theory: History, State of the Art and Advancements." Research in Engineering Design 24(2), 97-103.

Liedtka, J., R. Salzman and D. Azer. 2018. "Design Thinking for the Greater Good." Rotman Management (Spring), 49-53.

Lilja, J., D. Hansen, J. Fredrikson and D. Richardsson. 2017. "Is Innovation the Future of Quality Management? Searching for Signs of Quality and Innovation Management Merging." International Journal of Quality and Service Sciences 9(3/4), 232-240.

Lindberg, T., R. Gumienny, B. Jobst and C. Meinel. 2010. "Is there a Need for a Design Thinking Process?" In Proceedings of Design Thinking Research Symposium 8, Sydney, Australia. Available at https://hpi.de/fileadmin/user_upload/ fachgebiete/meinel/papers/Design_Thinking/2010_Lindberg_Design.pdf (last accessed 4 April 2021).

Madsen, D. Ø. 2020. "Have the Reports of TQM's Death Been Greatly Exaggerated? A Re-Examination of the Concept's Historical Popularity Trajectory." Administrative Sciences 10(2), 1-25.

Mendel, J. 2012. "A Taxonomy of Models Used in the Design Process." Interactions 19(1), 81-85.

Micheli, P., S. J. S. Wilner, S. H. Bhatti, M. Mura and M. B. Beverland. 2018. "Doing Design Thinking: Conceptual Review, Synthesis, and Research Agenda." Journal of Product Innovation Management 13(20), 124-148.

Mintrom, M. and J. Luetjens. 2016. "Design Thinking in Policymaking Processes: Opportunities and Challenges." Australian Journal of Public Administration 75(3), 391-402. 
Mulgan, G. 2014. Design in Public and Social Innovation: What Works and What Could Work Better. Available at https://www.nesta.org.uk/report/design-in-public-and-social-innovation/ (last accessed 4 April 2021).

Raja Sreedharan, V., R. Raju and S. Srivatsa Srinivas. 2017. "A Review of the Quality Evolution in Various Organisations." Total Quality Management \& Business Excellence 28(3-4), 351-365.

Reeves, C. A. and D. A. Bednar. 1994. "Defining Quality: Alternatives and Implications." Academy of Management Review 19(3), 419-445.

Sabet, E., E. Adams and B. Yazdani. 2016. "Quality Management in Heavy Duty Manufacturing Industry: TQM vs. Six Sigma.” Total Quality Management 27(2), 215-225.

Sanders, E. B. N. and P. J. Stappers. 2008. "Co-Creation and the New Landscapes of Design." CoDesign 4(1), 5-18.

Sony, M., J. Antony and J. A Douglas. 2020. "Essential Ingredients for the Implementation of Quality 4.0: A Narrative Review of Literature and Future Directions for Research.” TQM Journal 32(4), 779-793.

Špaček, D. 2018. "Public Administration Reform in Czechia after 2000: Ambitious Strategies and Modest Results?" NISPAcee Journal of Public Administration and Policy 11(1), 155-182.

Špalková, D., D. Špaček and J. Nemec. 2015. "Performance Management and Performance Appraisal: Czech Self-Governments.” NISPAcee Journal of Public Administration and Policy 8(2), 69-88.

Swiss, J. E. 1992. “Adapting Total Quality Management (TQM) to Government.” Public Administration Review 52(4), 356-362.

Talbot, C. 2008. Measuring Public Value: A Competing Values Approach. London: The Work Foundation. Available at http://citeseerx.ist.psu.edu/viewdoc/ download?doi=10.1.1.608.3734\&rep=rep1\&type=pdf (last accessed 4 April 2021).

Tomaževič, N., J. Seljak and A. Aristovnik. 2014. “The Impact of CAF Enablers on Job Satisfaction: the Case of the Slovenian Law Enforcement Agency." Total Quality Management \& Business Excellence 25(11-12), 1336-1351.

van der Wal, Z. 2017. The $21^{\text {st }}$ Century Public Manager. London, UK: Palgrave.

van der Wiele, A., B. G. Dale and A. R. T. Williams. 1997. "ISO 9000 Series Registration to Total Quality Management: The Transformation Journey." International Journal of Quality Science 2(4), 236-252.

van Kemenade, E. and T. Hardjono. 2019. “Twenty-First Century Total Quality Management: The Emergence Paradigm.” TQM Journal 31(2), 150-166. 
The Potential of Design Thinking and Total Quality Management in Creating Public...

Vinni, R. 2007. "Total Quality Management and Paradigms of Public Administration." International Public Management Review 8(1), 103-128.

Weckenmann, A., G. Akkasoglu and T. Werner. 2015. "Quality Management: History and Trends." TQM Journal 27(3), 281-293.

Yong, J. and A. Wilkinson. 2001. "Rethinking Total Quality Management." Total Quality Management 12(2), 247-258. 